\title{
Arginine 482 to glycine mutation in ABCG2/BCRP increases etoposide transport and resistance to the drug in HEK-293 cells
}

\author{
LAHCEN EDDABRA $^{1}$, THOMAS WENNER ${ }^{2}$, HASSAN EL BTAOURI ${ }^{1}$, THOMAS BARANEK ${ }^{3}$, \\ CLAUDIE MADOULET $^{1}$, PASCALE CORNILLET-LEFEBVRE ${ }^{4}$ and HAMID MORJANI $^{1}$ \\ ${ }^{1}$ MEDyC Unité CNRS UMR6237, UFR de Pharmacie, IFR53, 51096 Reims, France; ${ }^{2}$ CRP-Santé, Luxembourg; \\ ${ }^{3}$ IIER EA 4303, UFR Médecine, IFR53; ${ }^{4}$ EA3801, Laboratoire d'Hématologie, \\ CHU de Reims, 51096 Reims, France
}

Received July 13, 2011; Accepted August 16, 2011

DOI: $10.3892 / o r .2011 .1468$

\begin{abstract}
Resistance to etoposide has been associated with the overexpression of P-glycoprotein and MRP1 in human tumor cells. However, the role of BCRP in resistance to etoposide has not been clearly established, especially the significance of arginine 482 mutations in drug transport (cellular uptake and efflux). Different levels of resistance to etoposide have been recently observed in cells expressing BCRP in terms of cytotoxicity. The aim of this work was to study the effects of these mutations on the functional involvement of BCRP in etoposide transport. HEK293 cells were transfected with an empty vector $(\mathrm{HEK} / \mathrm{V})$, the vector bearing the wild-type BCRP (HEK/R482), the mutant arginine-482-glycine (HEK/R482G) or the mutant arginine-482-threonine (HEK/R482T). MTT assay was used to study the cytotoxic effect of etoposide and $\left[{ }^{3} \mathrm{H}\right]$-etoposide was used to determine cellular drug uptake and efflux. Data show that HEK/R482G cells displayed the highest levels of resistance to etoposide. Cellular $\left[{ }^{3} \mathrm{H}\right]$-etoposide uptake was lower in HEK/R482, HEK/R482G and HEK/R482T cells compared to HEK/V cells. In addition, cellular $\left[{ }^{3} \mathrm{H}\right]$-etoposide uptake in HEK/R482G was the lowest. Drug efflux measurements showed that fumitremorgin $\mathrm{C}$ was able to increase the residual cellular $\left[{ }^{3} \mathrm{H}\right]$-etoposide uptake in BCRP-transfected cells and especially in HEK/R482G ones. Our data show that the $\mathrm{R} 482 \mathrm{G}$ mutation in BCRP is able to increase efflux of etoposide and that mutation analysis at codon 482 may be of clinical importance in cancers treated with etoposide.
\end{abstract}

\section{Introduction}

One of the mechanisms of resistance to anticancer chemotherapy has been linked to the overexpression of $\mathrm{ABC}$ membrane transporters leading to the decrease of the

Correspondence to: Dr Hamid Morjani, MEDyC Unité CNRS UMR6237, UFR de Pharmacie, IFR53, 51096 Reims, France

E-mail: hamid.morjani@univ-reims.fr

Key words: ABCG2/BCRP, mutation, etoposide transport, resistance intracellular drug concentration. These proteins include P-glycoprotein/MDRl (ABCB1) (1), multidrug resistanceassociated protein/MRP (ABCC) (2) and the ABC half transporter breast cancer resistance protein/BCRP (ABCG2) $(3,4)$.

Resistance to etoposide has been mainly associated with the overexpression of P-glycoprotein and MRP1 $(1,2)$. Different levels of resistance to etoposide have been recently observed in cells expressing BCRP $(5,6)$. Murine cells selected for resistance to doxorubicin that overexpress the mouse Bcrp1 gene were also resistant to etoposide (7). Moreover, the reduced cellular accumulation and resistance to etoposide in cells lacking P-glycoprotein (P-gp) and Mrp1 proteins have been related to the overexpression and/or amplification of the Bcrpl gene (8).

Human BCRP gene was initially identified in resistant breast carcinoma cells selected for resistance to doxorubicin and verapamil. In these cells the BCRP gene has been shown to be mutated in the exon 5 leading to the substitution of the arginine 482 for a threonine (R482T). The same amino acid is also mutated in another cell line but substituted for a glycine (R482G) $(9,10)$. The affinity of BCRP to several substrates has also been found altered by the mutation arginine $482(9,11)$.

Nevertheless, although the role of BCRP in etoposide resistance is well established in murine cells, its functional involvement in human in terms of drug transport (cellular uptake and efflux), as well as the significance of arginine 482 mutations has not been investigated. We studied the resistance to etoposide and its cellular transport in HEK293 cells transfected by the human wild-type BCRP or its R482G and R482T mutants. We show that cells expressing the R482G mutant display higher resistance level to etoposide than the wild-type $\mathrm{BCRP}$ or the mutant R482T genes.

\section{Materials and methods}

Drugs and chemicals. Etoposide was supplied by Merck (Lyon, France). $\left[{ }^{3} \mathrm{H}\right]$-etoposide $(25 \mu \mathrm{Ci} / \mathrm{mol})$ was obtained from Moravek Biochemicals (Brea, CA). Mitoxantrone, novobiocin and MTT were obtained from Sigma Chemicals (St. Quentin Fallavier, France). Fumitremorgin C (FTC) 
was kindly provided by R.W. Robey and Professor S. Bates (National Cancer Institute, NIH, Bethesda, MD, USA).

Cell lines. The human embryonic kidney HEK293 cells transfected with empty vector (HEK/V) or BCRP (HEK/R482 and HEK/R482G and HEK/R482T) were kindly provided by R.W. Robey and S. Bates (12). Cells were grown as monolayer in MEM (Invitrogen, Paris, France) supplemented with $10 \%$ fetal calf serum and $100 \mu \mathrm{g} / \mathrm{ml}$ penicillin, and $100 \mu \mathrm{g} / \mathrm{ml}$ streptomycin. The human ovarian carcinoma subline 2008/MRP1 which is stably transfected with MRPI cDNAs and their parental cells 2008 were kindly provided by Professor P. Borst (13). The 2008 cell lines were cultured in the RPMI-1640 (Invitrogen) supplemented with $10 \%$ fetal calf serum, $100 \mu \mathrm{g} / \mathrm{ml}$ penicillin and $100 \mu \mathrm{g} / \mathrm{ml}$ streptomycin.

$m R N A$ analysis. RNA was extracted from $5 \times 10^{6}$ cells using the RNAeasy mini kit and DNAse I (Qiagen, Paris, France) according to the manufacturer's instructions. Total RNA $(1 \mu \mathrm{g})$ was reverse transcribed using random hexamers, MMLV reverse transcriptase and reaction buffer provided in the Superscript First-Strand Synthesis System kit (Invitrogen). Real-time quantification was performed on the ABI Prism 7000 Sequence Detection System (Applied Biosystems, Foster City, USA) using $5 \mu \mathrm{l}$ of diluted cDNA, $350 \mathrm{nM}$ of forward and reverse primers and SYBR-Green PCR Master Mix in a 25- $\mu 1$ reaction volume under following conditions: $95^{\circ} \mathrm{C}$ for $10 \mathrm{~min}$, followed by 40 cycles of $94^{\circ} \mathrm{C}$ for $45 \mathrm{sec}, 60^{\circ} \mathrm{C}$ for $45 \mathrm{sec}, 72^{\circ} \mathrm{C}$ for $45 \mathrm{sec}$ and finally $72^{\circ} \mathrm{C}$ for $10 \mathrm{~min}$. Primers for $B C R P$ (forward 5'-CAGGTCTGTTTCAATCTCACA-3' and reverse 5'-TCCATATGGTGGAATGCTGAAG-3') and MRP1 (forward 5'-GAAGGCCATCGGACTCTTCA-3' and reverse CAGCGCGGACACATGGT) were designed using the Primer Express software (Applied Biosystems). Primers for TBP (forward 5'-GCACAGGAGCCAAGAGTGAA-3' reverse 5'-TCACAGCTCCCCACCATGTT-3') were used according to (14). Quantification of TBP as an endogenous control gene was performed to standardize the amount of cDNA added to each reaction. Data are presented as relative expression of $B C R P$ or $M R P 1$ using the comparative threshold cycle $(\mathrm{Ct})$ method. $\Delta \mathrm{Ct}$ is the difference of $\mathrm{Ct}$ values of target gene and the houskeeping gene TBP. Relative expression of target genes in BCRP or MRPI transfected cells as compared to HEK/V or 2008 cells was expressed as $\Delta \Delta \mathrm{Ct}=\Delta \mathrm{Ct}$ (BCRP- or MRPl-transfected cells) $\triangle \mathrm{Ct}$ (HEK/V or 2008). The $\mathrm{N}$-fold expression in target genes of $B C R P$ or $M R P I$ was expressed as $\mathrm{N}=2^{-\Delta \Delta \mathrm{Ct}}(15)$.

Flow cytometry analysis. The cells were fixed and permeabilized using IntraPrep as recommended by the manufacturer (Immunotech, Marseille, France). Cells were incubated $45 \mathrm{~min}$ at $4^{\circ} \mathrm{C}$ with the monoclonal antibodies BXP34 at $5 \mu \mathrm{g} / \mathrm{ml}$ (Alexis Biochemicals, San Diego, CA) or MRPm6 at $2.5 \mu \mathrm{g} / \mathrm{ml}$ (Alexis Biochemicals, San Diego, CA) for BCRP and MRP1 labelling respectively. For control, cells were incubated with the mouse IgG1 isotype (Dako A/S, Trappes, France). Protein detection was detected with the $\mathrm{F}\left(\mathrm{ab}^{\prime}\right) 2$ fragment of rabbit antimouse IgG-FITC diluted to 1/50 (Immunotech). Cells were analysed using a flow cytometer Becton-Dickinson (Mountain View, CA, USA). FITC was excited at $488 \mathrm{~nm}$ with an argon ion laser. Fluorescence emission was collected after passage through a 530-nm band pass filter. Data protein expression was determined as ratio of mean fluorescence of monoclonal antibodies MRPm6/IgG1 or BXP-34/IgG1 control.

MTT cytotoxicity assay. Cells were plated in flat-bottom 96-well plates at a density of 2000 cells per well and allowed to attach for $24 \mathrm{~h}$ at $37^{\circ} \mathrm{C}$ in $5 \% \mathrm{CO}_{2}$. Drugs at various concentrations with or without novobiocin $(10 \mu \mathrm{M})$ or FTC $(1 \mu \mathrm{M})$ were added to the cells before incubation for $72 \mathrm{~h}$. A solution of MTT $\left(20 \mu 1,2.5 \mathrm{mg} / \mathrm{ml}\right.$ ) was added to each well for $3 \mathrm{~h}$ at $37^{\circ} \mathrm{C}$. Medium was then removed and $200 \mu \mathrm{l}$ of dimethylsulfoxide was added to each well. Optical densities were measured at $540 \mathrm{~nm}$ using a series 750 microplate reader (Cambridge Technology, Watertown, MA, USA). The $\mathrm{IC}_{50}$ was determined as the drug concentration which resulted in a $50 \%$ growth inhibition. Resistance factor (RF) was calculated by dividing the $\mathrm{IC}_{50}$ obtained for the resistant cell line by the $\mathrm{IC}_{50}$ obtained for the parental cell line.

Etoposide accumulation. Etoposide accumulation was performed by $24 \mathrm{~h}$ pre-plating of $5 \times 10^{5}$ cells/well in 6 -well plates. Wells were then refreshed with $1 \mathrm{ml}$ of complete medium containing $2 \mu \mathrm{M}$ etoposide spiked with $0.2 \mu \mathrm{Ci} / \mathrm{ml}\left[{ }^{3} \mathrm{H}\right]$-etoposide (Moravek, Brea, CA), with or without $10 \mu \mathrm{M}$ FTC or $100 \mu \mathrm{M}$ novobiocin. After incubation for $2 \mathrm{~h}$ at $37^{\circ} \mathrm{C}$, plates were then placed on ice, the medium was removed, and cells were washed once with icecold PBS and then solubilized with $0.2 \mathrm{ml}$ of Solvable (Packard, Meridian, CT). Etoposide content was determined by scintillation counting. All drug cellular accumulation measurement were performed in triplicate wells.

Drug efflux. For drug efflux analysis, cells were preloaded with $2 \mu \mathrm{M}\left[{ }^{3} \mathrm{H}\right]$-etoposide for $2 \mathrm{~h}$. The cells were washed with PBS after incorporation of the drugs. Then the cells were incubated in fresh medium containing or not $10 \mu \mathrm{M}$ FTC for $1 \mathrm{~h}$. After incubation, $\left[{ }^{3} \mathrm{H}\right]$-etoposide remaining in the cells was measured as described above.

Statistical analysis. Values are means \pm SD. Means were considered to be significantly different using an appropriate unpaired t-test.

\section{Results}

BCRP and MRPI mRNA analysis in transfected cells. Realtime quantification PCR assays have been performed determine the relative expression level of $B C R P$ and $M R P 1$ mRNA. A high expression level of $B C R P$ mRNA was observed in HEK293 cells transfected with the BCRP genes, as compared to HEK/V cell line (Table I). The relative expression level of BCRP mRNA in HEK/R482, HEK/R482G and HEK/R482T cell lines was 347-, 247- and 315-fold and is higher than in HEK/V cells, respectively. The relative expression level of MRP1 mRNA was 35-fold higher in 2008/MRP1 cell line than in parental 2008 cell line.

BCRP protein expression. Flow cytometry was used to determine the BCRP expression in HEK293 cells (Fig. 1 and Table II). BCRP-transfected cells presented an increased BCRP protein level, as compared to HEK/V cells. As previously 
Table I. Relative mRNA expression levels of $B C R P$ and $M R P 1$ as estimated by real-time RT-PCR in HEK293 and 2008 transfected cells. ${ }^{\mathrm{a}}$

\begin{tabular}{lcccccc}
\hline & HEK/V & HEK/R482 & HEK/R482G & HEK/R482T & 2008 & 2008/MRP1 \\
\hline Ct TBP & 21.20 & 20.59 & 20.43 & 20.07 & 25.13 & 25.31 \\
Ct BCRP & 28.41 & 19.36 & 19.69 & 18.98 & - & - \\
Ct MRP1 & - & - & - & - & 27.20 & 22.23 \\
$\Delta \mathrm{Ct}$ & 7.21 & -1.23 & -0.74 & -1.09 & 2.07 & -3.08 \\
$\Delta \Delta \mathrm{Ct}$ & - & -8.44 & -7.95 & -8.30 & - & -5.15 \\
$2^{-\Delta \Delta \mathrm{Ct}}$ & - & 347.29 & 247.28 & 315.17 & - & 35.51 \\
\hline
\end{tabular}

${ }^{a}$ The fold change of $B C R P$ or $M R P 1$ expression in the $B C R P$ - and $M R P 1$-transfected cell lines was determined as described in Materials and methods. Results represent the mean of three independent RNA extractions.

Table II. Flow cytometry analysis of MDR proteins in HEK/293 and 2008 cells. Protein expression was determined as ratio of mean fluorescence of monoclonal antibodies MRPm6/IgG1 or BXP-34/IgG1 control.

\begin{tabular}{lcccccc}
\hline & HEK/V & HEK/R482 & HEK/R482G & HEK/R482T & 2008 & 2008/MRP1 \\
\hline BCRP & 1.56 & 20 & 25 & 21 & - & - \\
MRP1 & - & - & - & - & 1.02 & 4.44 \\
\hline
\end{tabular}
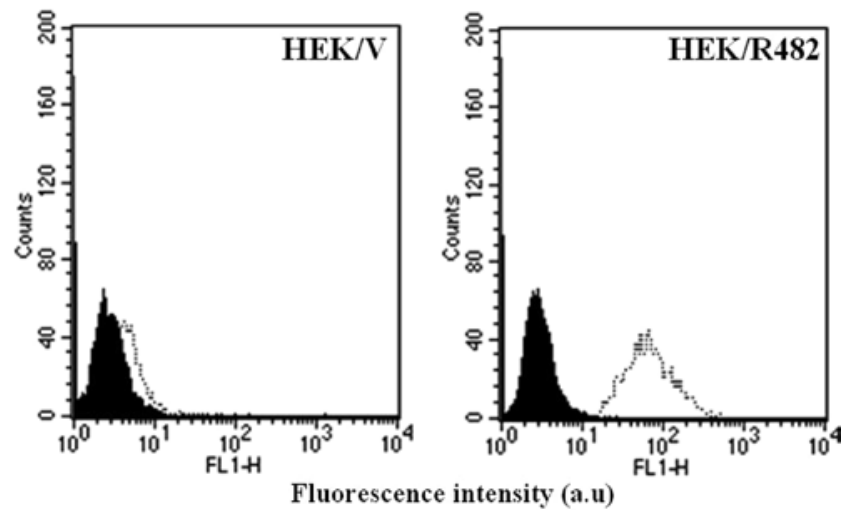

Figure 1. Analysis of BCRP protein expression in HEK/V and HEK/R482 cells by flow cytometry. Each histogram shows the overlay of the specific BXP34 antibody (white) with the isotype IgG1 control (black).

reported, BCRP protein levels are similar between wild-type and mutants (12). According to data reported by Hooijberg et al (13), a 4.3-fold increased expression of MRP1 was observed in 2008/MRP1 cells as compared to 2008 cells (Table II).

Cytotoxic effects of mitoxantrone and etoposide. The cytotoxic effect of etoposide has been determined in BCRP-transfected cells and in control HEK/V cells. As control, experiments have also been performed using the well-known BCRP substrate, mitoxantrone (16) and 2008/MRP1 cell line as a positive control for etoposide resistance (17) (Fig. 2 and Table III).

Results indicate that the expression of wt BCRP (HEK/ R482) confers 5-fold resistance to etoposide, as compared to parental cells $(\mathrm{HEK} / \mathrm{V})$. Interestingly, the resistance factor was significantly increased to 30 -fold in the glycine mutant

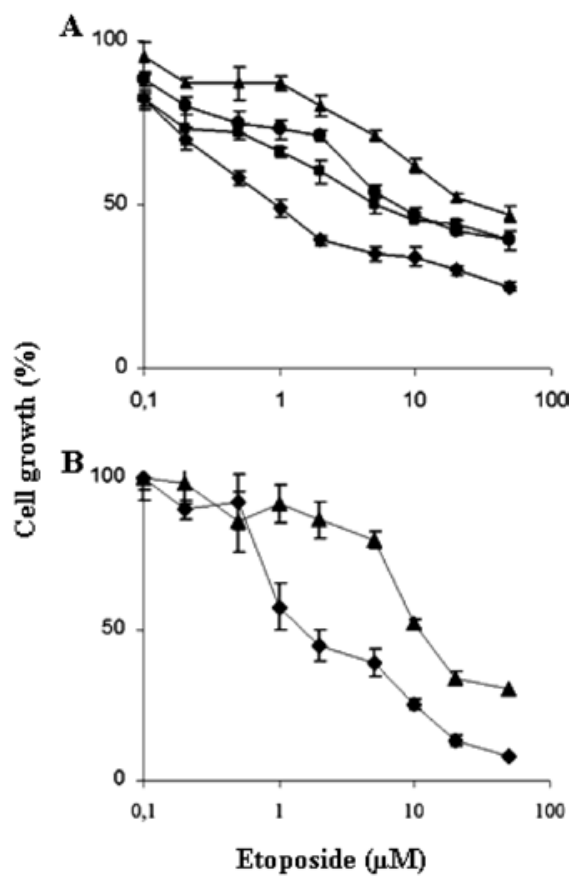

Figure 2. (A) Cytotoxic effect of etoposide in HEK293 (•), HEK/R482 (•),

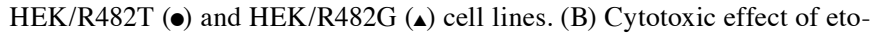
poside in 2008 (•) and 2008/MRP1 (₫) cells. Cell growth was determined using MTT assay. Standard deviation has been calculated with five independent experiments.

(HEK/R482G). In contrast, resistance to etoposide in HEK/ R482T cell line remains in the same range of HEK/R482 cell line. For mitoxantrone, the resistance observed was not significantly different between HEK/R482 cell line and the 
Table III. IC $_{50}$ of mitoxantrone and etoposide in HEK293 and 2008 cells in the presence or not of novobiocin or FTC.

\begin{tabular}{|c|c|c|c|c|c|c|c|c|c|c|c|}
\hline \multirow[b]{3}{*}{ Drug } & \multirow[b]{3}{*}{ Inhibitor } & \multicolumn{10}{|c|}{ Cell line } \\
\hline & & \multirow{2}{*}{$\frac{\mathrm{HEK} / \mathrm{V}}{\mathrm{IC}_{50}}$} & \multicolumn{2}{|c|}{ HEK/R482 } & \multicolumn{2}{|c|}{$\mathrm{HEK} / \mathrm{R} 482 \mathrm{G}$} & \multicolumn{2}{|c|}{ HEK/R482T } & \multirow{2}{*}{$\frac{2008}{\mathrm{IC}_{50}}$} & \multicolumn{2}{|c|}{ 2008/MRP1 } \\
\hline & & & $\mathrm{IC}_{50}$ & $\mathrm{RF}$ & $\mathrm{IC}_{50}$ & $\mathrm{RF}$ & $\mathrm{IC}_{50}$ & $\mathrm{RF}$ & & $\mathrm{IC}_{50}$ & $\mathrm{RF}$ \\
\hline \multirow[t]{3}{*}{ Mitoxantrone } & - & 0.15 & 1.17 & 11.33 & 3.10 & 20.67 & 3.00 & 20.00 & & & \\
\hline & Novobiocin & 0.08 & 0.08 & 1.00 & 0.50 & 6.25 & 0.90 & 11.25 & & & \\
\hline & FTC & 0.12 & 0.11 & 0.92 & 0.21 & 1.75 & 0.32 & 2.67 & & & \\
\hline \multirow[t]{3}{*}{ Etoposide } & - & 1.00 & 5.00 & 5.00 & 30.00 & 30.00 & 8.00 & 8.00 & 0.70 & 6.00 & 8.57 \\
\hline & Novobiocin & 1.00 & 2.00 & 2.00 & 4.50 & 4.50 & 8.20 & 8.20 & & & \\
\hline & FTC & 1.00 & 1.30 & 1.30 & 8.20 & 8.20 & 3.20 & 3.20 & & & \\
\hline
\end{tabular}

${ }^{a} \mathrm{IC}_{50}$ values are the means of three independent experiments, each performed in triplicate. Resistance factor $(\mathrm{RF})$ is the ratio of the $\mathrm{IC}_{50}$ observed in MRP1- or BCRP-transfected cells and the $\mathrm{IC}_{50}$ observed in vector transfected cells.

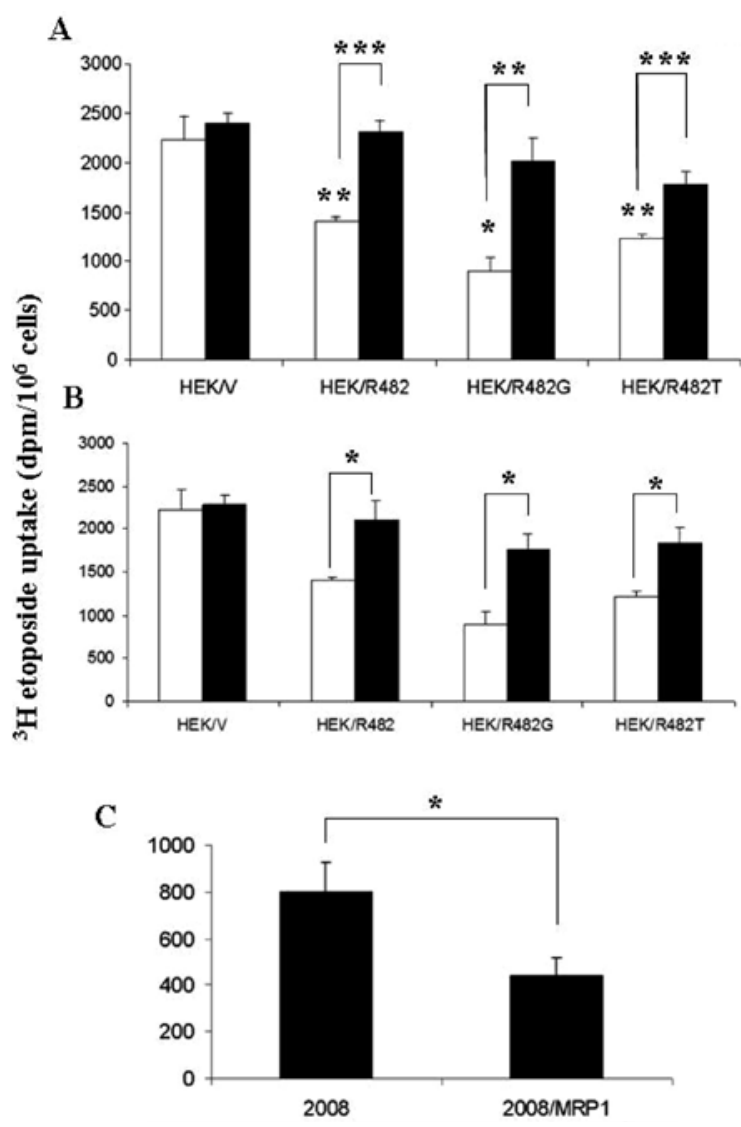

Figure 3. $\left[{ }^{3} \mathrm{H}\right]$-etoposide uptake after a 2-h treatment of HEK293 cells in the presence (black columns) or absence (white columns) of $100 \mu \mathrm{M}$ novobiocin (A) or $10 \mu \mathrm{M}$ FTC (B). (C) $\left[{ }^{3} \mathrm{H}\right]$-etoposide uptake in 2008 and 2008/MRP1 cells. Cells were incubated with $\left[{ }^{3} \mathrm{H}\right]$-etoposide $(2 \mu \mathrm{M})$ for $2 \mathrm{~h}$. Standard deviation has been calculated with three independent experiments. DPM: disintegration per minute. ${ }^{*} \mathrm{p}<0.01 ;{ }^{* *} \mathrm{p}<0.02 ;{ }^{* * *} \mathrm{p}<0.05$.

two mutants and was ranging between 11- to 20-fold (Fig. 3 and Table III).

The resistance to mitoxantrone and etoposide in HEK/ R482 cells was modulated by the BCRP inhibitors novobiocin $(18,19)$ and FTC $(20)$ (Table III). However, novobiocin was able to modulate resistance to etoposide to a lesser extent than FTC.

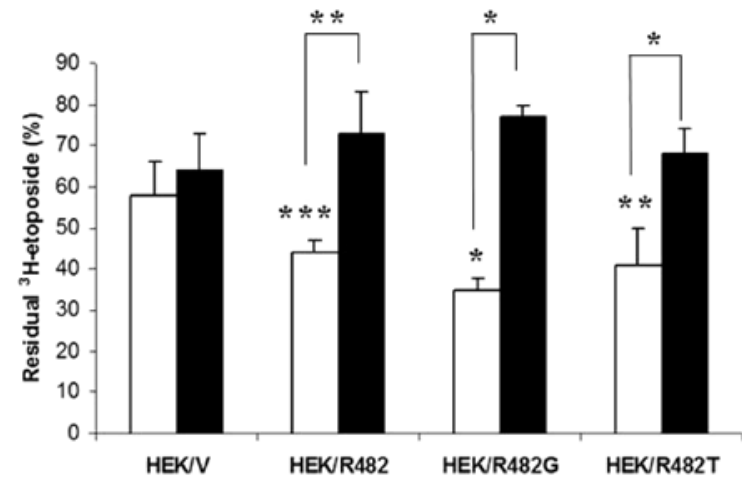

Figure 4. Intracellular residual $\left[{ }^{3} \mathrm{H}\right]$-etoposide in HEK293 cell lines. Cells were treated with $2 \mu \mathrm{M}\left[{ }^{3} \mathrm{H}\right]$-etoposide for $2 \mathrm{~h}$, then washed and incubated in fresh medium for $1 \mathrm{~h}$ in the presence (black column) or not (white column) of $10 \mu \mathrm{M}$ FTC. Cells were washed before measurement of cellular residual $\left[{ }^{3} \mathrm{H}\right]$-etoposide. Data are the means of three independent experiments. " $\mathrm{p}<0.01$; ${ }^{* * *} \mathrm{p}<0.02 ;{ }^{* * * *} \mathrm{p}<0.05$.

By contrast, FTC was able to reverse resistance to etoposide moderately in HEK/R482G cell line as compared to novobiocin. Novobiocin was not able to modulate resistance to etoposide in HEK/R482T cell line. This suggests that mutant BCRP proteins presented altered properties for pharmacologic modulation (Table III).

Intracellular accumulation of etoposide is reduced in BCRP-transfected cells. The difference between the levels of resistance to etoposide shown in Table III suggested that mutant BCRP may induce an alteration of the cellular accumulation of etoposide. To address this issue, intracellular accumulations of $\left[{ }^{3} \mathrm{H}\right]$-etoposide were measured in vector and BCRP-transfected HEK293 cells after $2 \mathrm{~h}$ of treatment (Fig. 3A and B).

The $\left[{ }^{3} \mathrm{H}\right]$-etoposide uptake represented $63(\mathrm{p}<0.02), 40$ $(\mathrm{p}<0.01)$ and 54\% (p<0.02), respectively, in HEK/R482, HEK/ R482G and HEK/R482T, of the value measured in HEK/V cells (Fig. 3A and B). Moreover, the $\left[{ }^{3} \mathrm{H}\right]$-etoposide uptake is significantly reduced in HEK/R482G cells as compared to HEK/ $\mathrm{R} 482$ cells $(\mathrm{p}<0.05)$. The $\left[{ }^{3} \mathrm{H}\right]$-etoposide uptake is also reduced in HEK/R482T cells as compared to HEK/R482 cells, although 
this does not reach stastical significance. As a positive control, [ $\left.{ }^{3} \mathrm{H}\right]$-etoposide uptake in $2008 / M R P 1$ cells was estimated and compared to 2008 cells. The uptake of $\left[{ }^{3} \mathrm{H}\right]$-etoposide in 2008/ $M R P 1$ cells is reduced by 2 -fold ( $\mathrm{p}<0.01)$, as compared to 2008 cells (Fig. 3C).

In order to confirm these data, we treated the cells simultaneously with etoposide and $100 \mu \mathrm{M}$ novobiocin. In all BCRP-transfected cell lines the intracellular concentration of $\left[{ }^{3} \mathrm{H}\right]$-etoposide has been found increased (Fig. 3A). $\left[{ }^{3} \mathrm{H}\right]$-etoposide uptake reached $92(\mathrm{p}<0.05), 77(\mathrm{p}<0.02)$ and $81 \%(\mathrm{p}<0.05)$ in HEK/R482, HEK/R482G and HEK/R482T cells, respectively, when compared to the values observed in the absence of novobiocin. Moreover, a similar effect was observed when BCRP-transfected cells were treated with $10 \mu \mathrm{M}$ FTC (Fig. 3B). This suggests that the resistance to etoposide is actually due to its transport by BCRP.

Etoposide efflux. In order to confirm the transport of etoposide by BCRP, we examined the efflux of etoposide in BCRPtransfected HEK293 cells. Cells were treated with $2 \mu \mathrm{M}$ [ $\left.{ }^{3} \mathrm{H}\right]$-etoposide for $2 \mathrm{~h}$, and washed out, in the presence or not of FTC, for an additional hour. All the intracellular $\left[{ }^{3} \mathrm{H}\right]$-etoposide concentrations were normalized with the intracellular concentrations measured before the washes. In the absence of FTC, after $1 \mathrm{~h}$ of washing, the intracellular $\left[{ }^{3} \mathrm{H}\right]$-etoposide concentration was of $58 \%$ of the initial concentration in HEK/V cells. However, in transfected cells it represented $44(\mathrm{p}<0.05), 35$ $(\mathrm{p}<0.01)$ and $41 \%(\mathrm{p}<0.02)$ of the initial concentration in HEK/ R482, HEK/R482G and HEK/R482T cells, respectively (Fig. 4). The intracellular $\left[{ }^{3} \mathrm{H}\right]$-etoposide concentration is significantly lower in HEK/R482G cells as compared to HEK/R482 cells $(\mathrm{p}<0.05)$. However, this does not reach stastical significance when HEK/R482T cells were compared to HEK/R482 cells. In the presence of FTC, cellular residual $\left[{ }^{3} \mathrm{H}\right]$-etoposide was not significantly increased in HEK/V cells (Fig. 4). However, in HEK/R482, HEK/R482G and HEK/R482T cells treated with FTC, the cellular residual $\left[{ }^{3} \mathrm{H}\right]$-etoposide was increased to 73 $(p<0.02), 77(p<0.01)$ and $68 \%(p<0.01)$ of the initial concentration, and was significantly higher than that observed in the absence of FTC (Fig. 4).

\section{Discussion}

The human BCRP has been shown to confer resistance to mitoxantrone, anthracyclines and camptothecins $(3,4)$. In drug-selected cell lines, two different mutations leading to a transition from arginine 482 to threonine (R482T) and glycine (R482G) respectively, have been observed $(9,10)$. $\mathrm{R} 482 \mathrm{~T}$ mutation confers high-level resistance to anthracyclines (21), and cells with R482G or R482T mutation are able to efflux more efficiently rhodamine 123 (9). Moreover, $\mathrm{R} 482 \mathrm{G}$ mutation seems to confer relatively less resistance to camptothecins. All these data suggest that amino acid 482 has a crucial role in BCRP function and that mutation of this amino acid significantly changes substrate specificity, thus altering the drug resistance phenotype.

BCRP has been recently involved in resistance to etoposide. Moreover, when P-glycoprotein (P-gp)- and Mrp1-deficient mouse cells are selected for resistance to etoposide, amplification and overexpression of Bcrpl emerged as the dominant resis- tance mechanism (8). In order to study the role of this protein in resistance to etoposide in human, we used the embryonic HEK 293 cells transfected with the wild-type BCRP (HEK/ R482) or its two mutants R482G (HEK/R482G) and R482T (HEK/R482T) (5). As compared with HEK/V cells, all of transfected cell lines displayed resistance to mitoxantrone and transported efficiently the BCRP substrate Hoechst 33342 (Table III and data not shown). Determination of rhodamine 123 uptake confirmed that HEK/R482G and HEK/R482T cells transported efficiently this probe when compared with HEK/R482 cells (data not shown).

In our study, we have shown that wild-type BCRP, R482T and especially $\mathrm{R} 482 \mathrm{G}$ mutant can confer significant resistance to etoposide, the $\mathrm{HEK} / \mathrm{R} 482 \mathrm{G}$ cells showing an $\mathrm{IC}_{50}$ value six-fold higher than in HEK/R482 cells (Table III). In this case, the resistance may be correlated with a decrease in the etoposide intracellular concentration (Fig. 3). Nevertheless, HEK/R482 and HEK/R482T cells were only 5- and 8-fold resistant, respectively, to etoposide (Table III). This suggest that $\mathrm{R} 482 \mathrm{G}$ mutation confer to the BCRP protein a better affinity for etoposide than the mutation R482T, or a better efficiency in drug efflux, as suggested by our results (Fig. 3).

The BCRP inhibitors FTC and novobiocin was able to significantly modulate resistance to etoposide and with a higher efficiency in the two mutants (Table III). In the presence of FTC, cellular uptake of etoposide was significantly increased and particularly in HEK/R482 and HEK/R482G cells. Etoposide efflux measurements showed that inhibition of BCRP with FTC leads to a significant increase in intracellular concentration of etoposide in BCRP-transfected cell lines, as compared to untreated cells (Fig. 4). Allen and co-workers have shown that Bcrp1-mediated etoposide resistance was reversed by two structurally different BCRP/ Bcrp1 inhibitors, GF120918 and Ko143 (8). The same authors suggested that mutation at R482 was not necessary for Bcrp1mediated resistance to etoposide because the Bcrp1 expressed in the etoposide-resistant cells was wild-type at this position (22). Our data show clearly that R482G mutation is able to increase resistance to etoposide. Since several recent studies have demonstrated the role of BCRP expression in drug resistance in cancer (4) and given previous evidence that even low levels of drug transporters may have a substantial effect on the basal resistance to substrate drugs (23), BCRP may be taken into account as a potential contributor to resistance to etoposide. Finally, the mutation analysis at codon 482 of BCRP may be of great importance in clinical cancers treated with etoposide. Recently, only two studies have analysed the BCRP mRNA sequence on patient samples $(24,25)$.

\section{Acknowledgements}

We would like to thank Gérard Simon and Annick Dupont for their excellent technical assistance, and Professor P. Borst from the Netherlands Cancer Institute (Amsterdam, the Netherlands) for the generous gift of 2008 cell lines. We thank also Dr R.W. Robey and Professor S. Bates from the Cancer Therapeutics Branch (Center for Cancer Research, National Cancer Institute, NIH, Bethesda, MD) for the generous gift of fumitremorgin C and HEK293 cell lines. 


\section{References}

1. Gottesman MM and Pastan I: Biochemistry of multidrug resistance mediated by the multidrug transporter. Annu Rev Biochem 62: 385-427, 1993.

2. Borst P, Evers R, Kool M and Wijnholds J: A family of drug transporters: the multidrug resistance-associated proteins. J Natl Cancer Inst 92: 1295-1302, 2000.

3. Litman T, Druley TE, Stein WD and Bates SE: From MDR to MXR: new understanding of multidrug resistance systems, their properties and clinical significance. Cell Mol Life Sci 58: 931-959, 2001.

4. Doyle LA and Ross DD: Multidrug resistance mediated by the breast cancer resistance protein BCRP (ABCG2). Oncogene 22: 7340-7358, 2003.

5. Robey RW, Honjo Y, Morisaki K, Nadjem TA, Runge S, Risbood M, Poruchynsky MS and Bates SE: Mutations at aminoacid 482 in the ABCG2 gene affect substrate and antagonist specificity. Br J Cancer 89: 1971-1978, 2003.

6. Volk EL, Rohde K, Rhee M, McGuire JJ, Doyle LA, Ross DD and Schneider E: Methotrexate cross-resistance in a mitoxantrone-selected multidrug-resistant MCF7 breast cancer cell line is attributable to enhanced energy-dependent drug efflux. Cancer Res 60: 3514-3521, 2000.

7. Allen JD, Brinkhuis RF, Wijnholds $\mathbf{J}$ and Schinkel AH: The mouse Bcrp1/Mxr/Abcp gene: amplification and overexpression in cell lines selected for resistance to topotecan, mitoxantrone, or doxorubicin. Cancer Res 59: 4237-4241, 1999.

8. Allen JD, Van Dort SC, Buitelaar M, van Tellingen O and Schinkel AH: Mouse breast cancer resistance protein (Bcrp1/ Abcg2) mediates etoposide resistance and transport, but etoposide oral availability is limited primarily by P-glycoprotein. Cancer Res 63: 1339-1344, 2003.

9. Honjo Y, Hrycyna CA, Yan QW, Medina-Perez WY, Robey RW, van de Laar A, Litman T, Dean M and Bates SE: Acquired mutations in the MXR/BCRP/ABCP gene alter substrate specificity in MXR/BCRP/ABCP-overexpressing cells. Cancer Res 61: 6635-6639, 2001.

10. Miyake K, Mickley L, Litman T, Zhan Z, Robey R, Cristensen B, Brangi M, Greenberger L, Dean M, Fojo T and Bates SE: Molecular cloning of cDNAs which are highly overexpressed in mitoxantrone-resistant cells: demonstration of homology to ABC transport genes. Cancer Res 59: 8-13, 1999.

11. Komatani H, Kotani H, Hara Y, Nakagawa R, Matsumoto M, Arakawa $\mathrm{H}$ and Nishimura S: Identification of breast cancer resistant protein/mitoxantrone resistance/placenta-specific ATP-binding cassette transporter as a transporter of NB-506 and J-107088, topoisomerase I inhibitors with an indolocarbazole structure. Cancer Res 61: 2827-2832, 2001.

12. Chen ZS, Robey RW, Belinsky MG, Shchaveleva I, Ren XQ, Sugimoto Y, Ross DD, Bates SE and Kruh GD: Transport of methotrexate, methotrexate polyglutamates, and 17beta-estradiol 17-(beta-D-glucuronide) by ABCG2: effects of acquired mutations at R482 on methotrexate transport. Cancer Res 63: 4048-4054, 2003.
13. Hooijberg JH, Broxterman HJ, Kool M, Assaraf YG, Peters GJ, Noordhuis P, Scheper RJ, Borst P, Pinedo HM and Jansen G: Antifolate resistance mediated by the multidrug resistance proteins MRP1 and MRP2. Cancer Res 59: 2532-2535, 1999.

14. Lossos IS, Czerwinski DK, Wechser MA and Levy R: Optimization of quantitative real-time RT-PCR parameters for the study of lymphoid malignancies. Leukemia 17: 789-795, 2003.

15. Ginzinger DG: Gene quantification using real-time quantitative PCR: an emerging technology hits the mainstream. Exp Hematol 30: 503-512, 2002 .

16. Litman T, Brangi M, Hudson E, Fetsch P, Abati A, Ross DD, Miyake K, Resau JH and Bates SE: The multidrug-resistant phenotype associated with overexpression of the new ABC halftransporter, MXR (ABCG2). J Cell Sci 113: 2011-2021, 2000.

17. Schneider E, Horton JK, Yang CH, Nakagawa $\mathrm{M}$ and Cowan $\mathrm{KH}$ Multidrug resistance-associated protein gene overexpression and reduced drug sensitivity of topoisomerase II in a human breast carcinoma MCF7 cell line selected for etoposide resistance. Cancer Res 54: 152-158, 1994.

18. Yang CH, Chen YC and Kuo ML: Novobiocin sensitizes BCRP/ MXR/ABCP overexpressing topotecan-resistant human breast carcinoma cells to topotecan and mitoxantrone. Anticancer Res 23: 2519-2523, 2003

19. Shiozawa K, Oka M, Soda H, Yoshikawa M, Ikegami Y, Tsurutani J, Nakatomi K, Nakamura Y, Doi S, Kitazaki T, Mizuta Y, Murase K, Yoshida H, Ross DD and Kohno S: Reversal of breast cancer resistance protein (BCRP/ABCG2)-mediated drug resistance by novobiocin, a coumermycin antibiotic. Int J Cancer 108: 146-151, 2004

20. Rabindran SK, Ross DD, Doyle LA, Yang W and Greenberger LM: Fumitremorgin $\mathrm{C}$ reverses multidrug resistance in cells transfected with the breast cancer resistance protein. Cancer Res 60: 47-50, 2000.

21. Shafran A, Ifergan I, Bram E, Jansen G, Kathmann I, Peters GJ, Robey RW, Bates SE and Assaraf YG: ABCG2 harboring the Gly482 mutation confers high-level resistance to various hydrophilic antifolates. Cancer Res 65: 8414-8422, 2005.

22. Allen JD, Jackson SC and Schinkel AH: A mutation hot spot in the Bcrp1 (Abcg2) multidrug transporter in mouse cell lines selected for Doxorubicin resistance. Cancer Res 62: 2294-2299, 2002.

23. Allen JD, Brinkhuis RF, van Deemter L, Wijnholds J and Schinkel AH: Extensive contribution of the multidrug transporters P-glycoprotein and Mrp1 to basal drug resistance. Cancer Res 60: 5761-5766, 2000.

24. Nakanishi T, Karp JE, Tan M, Doyle LA, Peters T, Yang W, Wei D and Ross DD: Quantitative analysis of breast cancer resistance protein and cellular resistance to flavopiridol in acute leukemia patients. Clin Cancer Res 9: 3320-3328, 2003

25. Suvannasankha A, Minderman H, O'Loughlin KL, Nakanishi T, Greco WR, Ross DD and Baer MR: Breast cancer resistance protein (BCRP/MXR/ABCG2) in acute myeloid leukemia: discordance between expression and function. Leukemia 18: $1252-1257,2004$ 